\title{
EVALUATION OF COLD WATER AND VITAMIN C ON BROILER GROWTHDURING HOT-DRY SEASON IN SW NIGERIA
}

\author{
EVALUACIÓN DEL AGUA FRÍA Y LA VITAMINA C SOBRE EL CRECIMIENTO DE \\ BROILERS EN LA ESTACIÓN CÁLIDA-SECA EN SW NIGERIA
}

\begin{abstract}
Abioja, M.O. ${ }^{1}$, Osinowo, O.A. ${ }^{1}$, Smith, O.F. ${ }^{1}$, Eruvbetine, D. ${ }^{2}$ and Abiona, J.A. ${ }^{1}$
${ }^{1}$ Department of Animal Physiology. College of Animal Science and Livestock Production. University of Agriculture. Abeokuta. Nigeria.

${ }^{2}$ Department of Animal Nutrition. College of Animal Science and Livestock Production. University of Agriculture. Abeokuta. Nigeria.
\end{abstract}

\section{AdDitionAL KEYWORDS}

Heat stress. Feed intake. Weight gain. Feed conversion ratio. Spleen. Wings. Breast meat.

\section{SUMMARY}

A study to determine effects of cold water and vitamin C on growth performance in 216 Anak 2000 broiler chickens was carried out during hotdry season in the SW Nigeria. The minimum, maximum and mean temperatures during the experiment were $19.4,35.8$ and $27.6^{\circ} \mathrm{C}$ respectively while the relative humidity was $72.6 \%$. The broilers, Anak 2000 at d 28 were allotted to two groups offered either ordinary water $\left(29.5^{\circ} \mathrm{C}\right)$ or chilled water $\left(8.0^{\circ} \mathrm{C}\right)$ for four weeks. Each group was divided into two. Each half received either 0 or 500 $\mathrm{mg}$ vitamin $\mathrm{C}$ per litre in drinking water in $2 \times 2$ factorial arrangement. There were 3 replicates with 18 birds per replicate. Data on daily water intake (DWI), weekly feed intake (WFI), final liveweight (FLW), weekly weight gain (WWG), total weight gain (TWG), feed conversion ratio (FCR), percentage survival (SURV), and relative weights of breast meat, liver, spleen, gizzard, drumstick, thigh, heart and wing were subjected to analysis of variance. Water temperature had no significant effect on DWI, WFI, FCR and SURV. However, offering broiler chickens cold drinking water resulted in significantly higher WWG $(p<0.001)$, TWG $(p<0.001)$, FLW $(p<0.001)$ and relative weight of spleen $(p<0.001)$ compared to water at ambient temperature. Addition of $500 \mathrm{mg}$ vitamin $C$ per litre water increased significantly the relative weights of breast meat compared to $0 \mathrm{mg}$

\section{Palabras clave adicionales}

Estrés por calor. Ingestión de alimento. Ganacia de peso. Índice de conversión. Bazo. Alas. Pechuga. vitamin C. Other parameters were affected by vitamin $C$. There were not interaction between water temperature and addition of vitamin $\mathrm{C}$ on growth parameters examined in this study. It can therefore be concluded that offering cold water to broiler chickens during hot-dry season increases weight gain and spleen but reduced wing size. Though addition of vitamin $\mathrm{C}$ could not raised growth rate in broilers during hot-dry season, the breast meat yield was improved.

\section{RESUMEN}

Durante la estación cálida-seca en el SW de Nigeria se realizó un estudio para determinar los efectos del agua fría y la vitamina C sobre el crecimiento de 216 broilers Anak 2000. Las temperaturas mínima, media y máxima durante el experimento fueron 19,$4 ; 35,8$ y $27,6^{\circ} \mathrm{C}$ respectivamente y la humedad relativa fue de $72,6 \%$. El día 28 , los pollos fueron divididos en dos grupos a los que se suministró agua a temperatura normal $\left(29,5^{\circ} \mathrm{C}\right)$ o agua enfriada $\left(8,0^{\circ} \mathrm{C}\right)$ durante cuatro semanas. Cada grupo fue dividido en dos, recibiendo cada mitad 0 o $500 \mathrm{mg}$ de vitamina $C$ por litro de agua de bebida en un diseño factorial $2 \times 2$ se realizaron tres repeticiones con 18 aves por repetición. Los datos sobre ingestión diaria de agua (DWI), ingestión semanal de alimento (WFI), 
peso vivo final (FLW), ganancia de peso semanal (WWG), ganacia total de peso (TWG), tasa de conversión de alimento (FCR), porcentaje de supervivencia (SURV) y pesos relativos de pechuga, hígado, bazo, molleja, pata, muslo, corazón y ala, fueron sometidos al análisis de varianza. La temperatura del agua no tuvo efecto significativo sobre DWI, WFI, FCR y SURV. Sin embargo el consumo de agua fría por los pollos se tradujo en un aumento WWG ( $p<0,001)$, TWG $(p<0,001)$, FLW $(p<0,001)$ y peso relativo del bazo $(p<0,001)$ en comparación con el consumo de agua a temperatura ambiente. La adición de 500 mg de vitamina C por litro de agua incrementó significativamente el peso relativo de la pechuga, comparado con el suministro de $0 \mathrm{mg}$ de vitamina $\mathrm{C}$. Otras variables fueron influenciadas por la vitamina $C$. No se registró interacción entre la temperatura del agua y la vitamina $\mathrm{C}$ sobre los parámetros de crecimiento examinados en este estudio. Puede concluirse que el suministro de agua fría a los pollos durante la estación cálida-seca aumenta la ganacia de peso y del hígado, pero redujo el tamaño del ala. Aunque la adición de vitamina $C$ no aumentó la tasa de crecimiento en broilers durante la estación cálida-seca, el rendimiento de la pechuga mejoró.

\section{INTRODUCTION}

Chickens belong to a class of animals that regulate body temperature within a narrow range (Genç, 2005). This is only possible as long as they are maintained within their thermal comfort zone in ambient temperature. When the ambient temperature overshoot the thermal comfort zone, as the case commonly experienced in the tropical environment, the birds depends on panting and other behavioural responses to dissipate body heat. They lack sweat glands as in ruminant animals. There is consequential reduction in voluntary feed intake, so as to limit metabolic heat production (Hai et al., 2000) in order to lower the metabolic heat production. Moreover, they divert energy and other nutrients intended for growth, immunity and reproduction to thermoregulation, thereby limiting their productivity (Brake, 1987). Commercial broilers are more susceptible to heat stress because they depend on high feed intake and the inferior development of their respiratory and cardio-vascular systems compared with rate of growth (Yahav, 2000). Therefore heat-stressed broilers had retarded growth (Temim et al., 2000; Oskan et al., 2003; Abu-Dieyeh, 2006). This effect is more pronounced during the growing phase. To obtain optimal productivity in hot environment therefore, some management techniques have to be put in place to reduce the effects.

South-western Nigeria is located in the humid tropics, characterized by high ambient temperature of $>30^{\circ} \mathrm{C}$ (Abioja, 2005; Abioja et al., 2010) during hot-dry months (mid-January to mid-April). Wilson and Edward (1952) proposed that offering cold water to chickens could reduce adverse effects of heat stress. Broiler chickens grew faster (Harris et al., 1975) and had higher gain/feed ratio (Beker and Teeter, 1994) when given cold water under heat stress conditions. Similarly, Lofgreen et al. (1975) also reported that cold water improved daily weight gain in beef cattle. However, Okelo et al. (2003) reported that cold water had no effect on liveweight gain, feed/gain ratio and carcass yield. Many poultry handlers in Nigeria have been using crushed iced cubes to cool water to birds during hot periods. However, efficacy of this practice has not been scientifically proved in Nigeria. Dietary supplementation with vitamin $\mathrm{C}$ has been reported to be efficient in reducing effects of heat stress in chickens (Pardue et al., 1985; Pardue and Thaxton, 1986; Sahin, 2003; Mahmoud et al., 2004). Combining chilled water with vitamin $\mathrm{C}$ may be more useful. Therefore, this study is aimed at determining the effects of chilled water and addition of vitamin $\mathrm{C}$ to drinking water on growth performance in growing broiler chickens.

\section{MATERIALSAND METHODS}

Location: The study was carried out at Poultry Unit of University Teaching and 
Research Farms of University of Agriculture, Abeokuta, Nigeria (latitude $7^{\circ} 13$ ' 49.46" N; longitude $3^{\circ} 26^{\prime} 11.98 " \mathrm{E}$; altitude $76 \mathrm{~m}$ above sea level; Google Earth, 2006).

Meteorological conditions: Daily minimum, maximum and mean temperature, relative humidity and wet- and dry-bulb temperature were monitored at the level of the birds in the pens throughout the experimental period. Temperature-humidity index (THI) was calculated using the formula of Palmer (2000) as:

$\mathrm{THI}=-42.4+2.05(\mathrm{~T})+10.14(\mathrm{R})-0.225(\mathrm{~T} \times \mathrm{R})-6.84$ $\left(10^{-3} \times T^{2}\right)-5.48\left(10^{-2} \times R^{2}\right)+1.23\left(10^{-3} \times T^{2} \times R\right)+$ $8.53\left(10^{-4} \times T \times R^{2}\right)-1.99\left(10^{-6} \times T^{2} \times R^{2}\right)$

where,

T: dry air temperature;

$\mathrm{R}$ : relative humidity.

Experimental birds and management: Day-old broiler chicks of Anak 2000 strain were purchased from a reputable hatchery in Abeokuta, Nigeria early February of year 2009 and brooded for three weeks on woodshaving floor. They were given fresh water always and fed ad libitum with a standard diet containing $46 \%$ maize, $18.5 \%$ soybean meal, $15 \%$ groundnut cake, $2 \%$ fishmeal, $12.45 \%$ wheat offal, $2 \%$ bonemeal, $3 \%$ oyster shell, $0.25 \%$ salt, $0.25 \%$ premix, $0.3 \%$ methionine and 0.25 lysine. The birds were transferred to the deep-litter floor experimental pens where they were allowed a week for adjustment. The stocking density was $18 \mathrm{~kg}$ per $2 \mathrm{~m}^{2}$.

The broilers at $\mathrm{d} 28$ were allotted to two groups each offered either water at ambient temperature $\left(29.5^{\circ} \mathrm{C}\right)$ or chilled water $\left(8.0^{\circ} \mathrm{C}\right)$ for four weeks. Each group was divided into two homogenised by liveweight. Each half received either 0 or $500 \mathrm{mg}$ vitamin $C$ per litre in drinking water in $2 \times 2$ factorial arrangement. There were 3 replicates with 18 birds per replicate. Water for the experiment was solely sourced from a single well on the farm and supplied in nipple drinker lines linked to either water reservoir (for water at ambient temperature) or a refrigerating unit (for cold water). There was a pump to return the water from the lines to the refrigerating unit. The temperature of water was recorded by $08.00,12.00$ and 16.00 h daily.

Data collection and analyses: Records of daily water intake (DWI), weekly weight gain (WWG), feed intake (WFI) and percentage survival (SURV) in each replicate were taken throughout the experimental period. Percentage survival was calculated as: (number of birds that survive at the end of week $\div$ total number of birds at the beginning of each week) x 100 . The final liveweight (FLW) of the birds was taken at d56 as a group with the aid of a sensitive scale. Feed conversion ratio (FCR) was calculated as ratio of feed to weight gain. On d56, three birds from each replicate were randomly selected and sacrificed by exsanguinations. Liveweight, slaughter weight, dressed weight and weights of breast meat, liver, spleen, gizzard, drumstick, thigh, heart and wing were taken. Relative weights of the organs were calculated as organs weight divided by liveweight multiplied by 100.

Data collected were analysed by method of least squares of SYSTAT (1992) using model:

$$
Y_{i j k}=\mu+T_{i}+C_{j}+T C_{i j}+\Sigma_{i j k}
$$

where,

$\mathrm{Y}_{\mathrm{ijk}}=$ yield;

$\mu=$ population mean;

$\mathrm{T}_{\mathrm{i}}=\mathrm{i}_{\text {th }}$ effect due to water temperature;

$\mathrm{C}_{\mathrm{j}}=\mathrm{j}_{\text {th }}$ effect due to vitamin $\mathrm{C}$;

$\mathrm{TC}_{\mathrm{ij}}=\mathrm{ij}_{\mathrm{th}}$ effect due to interaction between water temperature and vitamin $\mathrm{C}$ and

$\Sigma_{\mathrm{ijk}}=$ residual error.

\section{RESULTS}

The summary of the climatic conditions during the experimental period is presented in table I. Average dry-bulb temperature 
Table I. Average daily values for meteorological parameters observed during the experimental period. (Valores medios diarios para los parámetros meteorológicos registrados durante el periodo experimental).

\begin{tabular}{|c|c|c|c|c|c|c|}
\hline & & & erature & $\left({ }^{\circ} \mathrm{C}\right)$ & & \\
\hline & Week & Min. & Max. & Mean & $\mathrm{RH}$ & THI \\
\hline & 5 & 20.1 & 36.6 & 28.4 & 68.4 & 163.7 \\
\hline & 6 & 19.1 & 36.6 & 27.9 & 70.1 & 165.3 \\
\hline & 7 & 18.7 & 34.9 & 26.8 & 73.2 & 167.1 \\
\hline & 8 & 19.7 & 35.4 & 27.6 & 78.9 & 166.6 \\
\hline & Av. & 19.4 & 35.8 & 27.6 & 72.6 & 165.7 \\
\hline & & WBT & DBT & & $\mathrm{RH}$ & THI \\
\hline & 5 & 25.9 & 27.9 & & 83.0 & 185.0 \\
\hline & 6 & 25.9 & 27.7 & & 84.1 & 185.7 \\
\hline ஹं & 7 & 26.4 & 27.8 & & 88.0 & 182.1 \\
\hline & 8 & 26.6 & 28.3 & & 85.5 & 180.2 \\
\hline & Av. & 26.2 & 27.9 & & 85.2 & 183.2 \\
\hline & 5 & 28.0 & 35.6 & & 53.7 & 142.4 \\
\hline & 6 & 28.2 & 35.3 & & 56.0 & 145.0 \\
\hline & 7 & 27.8 & 33.9 & & 58.4 & 152.2 \\
\hline & 8 & 30.3 & 34.1 & & 72.3 & 153.0 \\
\hline & Av. & 28.6 & 34.7 & & 60.1 & 148.1 \\
\hline
\end{tabular}

$\mathrm{RH}$ : relative humidity (\%); THI: Temp.-humidity index; WBT: Wet-bulb temp. $\left({ }^{\circ} \mathrm{C}\right)$; DBT: Dry-bulb temp. $\left({ }^{\circ} \mathrm{C}\right)$.

and relative humidity were $27.9^{\circ} \mathrm{C}$, and $85.2 \%$ by $08.00 \mathrm{~h}$, and $34.7^{\circ} \mathrm{C}$ and, $60.1 \%$ by 16.00 $\mathrm{h}$ respectively. The temperature of both ordinary and chilled water is shown in table
II. Ordinary water was $29.5^{\circ} \mathrm{C}$ while cold water was $8.0^{\circ} \mathrm{C}$. Table III shows the effects of water temperature and vitamin $\mathrm{C}$ on WWG, FLW, TWG between d28 and d56, DWI, WFI and FCR. Temperature of drinking water had significant $(\mathrm{p}<0.05)$ effect on average WWG in the birds. Averagely birds offered cold water gained $0.26 \mathrm{~kg} /$ week while bird on water at ambient temperature gained $0.2 \mathrm{~kg} /$ week. Addition of vitamin C did not ( $>0.05)$ affect WWG. Cold water significantly increased FLW $(\mathrm{p}<0.05)$ and TWG $(\mathrm{p}<0.05)$ compared with water at ambient temperature. However, water temperature had no significant ( $\mathrm{p}>0.05$ ) effect on DWI. The FLW and TWG in broiler chickens that received cold water were 1.529 and $1.028 \mathrm{~kg} /$ bird while the birds that received water at ambient temperature recorded 1.450 and $0.944 \mathrm{~kg} / \mathrm{bird}$ respectively. Addition of vitamin C did not ( $\mathrm{p}>0.05)$ affect FLW, TWG and DWI. Water temperature and addition of vitamin C to drinking water had no ( $\mathrm{p}>0.05)$ effect on WFI and there was no interaction between water temperature and vitamin C on WFI of the broiler birds.

FCR was not affected ( $>0.05$ ) by water temperature. The average FCR of birds offered water with or without vitamin $C$ was similar ( $\mathrm{p}>0.05)$.

Table IV shows effects of water temperature and vitamin $C$ on relative weight of body and internal organs of broiler chickens reared during hot-dry season. Water temperature had no effect $(p>0.05)$ on

Table II. Average temperature $\left({ }^{\circ} \mathrm{C}\right)$ of water supplied to the birds during the experimental period. (Temperatura media $\left({ }^{\circ} \mathrm{C}\right)$ del agua suministrada a las aves durante el periodo experimental).

\begin{tabular}{ccccccccc}
\hline \multirow{2}{*}{ Week } & \multicolumn{4}{c}{ ordinary water } & \multicolumn{5}{c}{ cold water } \\
\hline 5 & $08.00 \mathrm{~h}$ & $12.00 \mathrm{~h}$ & $16.00 \mathrm{~h}$ & Average & $08.00 \mathrm{~h}$ & $12.00 \mathrm{~h}$ & $16.00 \mathrm{~h}$ & Average \\
6 & 27.1 & 30.3 & 31.7 & 29.7 & 8.1 & 8.3 & 7.7 & 8.0 \\
7 & 26.9 & 30.4 & 31.6 & 29.6 & 7.4 & 7.3 & 6.3 & 7.0 \\
8 & 27.2 & 29.8 & 31.4 & 29.5 & 8.4 & 6.1 & 5.6 & 6.7 \\
Average & 27.4 & 29.7 & 31.2 & 29.4 & 11.3 & 10.0 & 8.9 & 10.4 \\
\hline
\end{tabular}

Archivos de zootecnia vol. 60, núm.232, p. 1098. 
Table III. Effects of water temperature and vitamin C supplementation on final liveweight, weight gain (kg/bird) and daily water intake (litres/bird) of broiler chickens reared during hot-dry season. (Efecto de la temperatura del agua y de la suplementación con vitamina C, sobre el peso vivo final, ganancia de peso ( $\mathrm{kg} / \mathrm{ave}$ ) e ingestion diaria de de agua (litros por ave) de broilers criados durante la estación cálida-seca).

\begin{tabular}{|c|c|c|c|c|c|c|c|c|}
\hline \multirow[b]{2}{*}{ Parameter } & \multicolumn{4}{|c|}{ water temperature } & \multicolumn{4}{|c|}{ vitamin C } \\
\hline & Ord & Cold & \pm SEM & $\mathrm{p}$ & $-\mathrm{C}$ & $+\mathrm{C}$ & \pm SEM & $\mathrm{p}$ \\
\hline Initial liveweight @ 4 weeks of age (kg) & 0.51 & 0.50 & 0.002 & 0.077 & 0.50 & 0.51 & 0.002 & 0.052 \\
\hline Final liveweight @8 weeks of age $(\mathrm{kg})$ & $1.45^{\mathrm{b}}$ & $1.53^{\mathrm{a}}$ & 0.024 & 0.047 & 1.45 & 1.53 & 0.024 & 0.134 \\
\hline Total weight gain $(\mathrm{kg})$ & $0.94^{\mathrm{b}}$ & $1.03^{\mathrm{a}}$ & 0.025 & 0.033 & 0.95 & 1.02 & 0.025 & 0.182 \\
\hline Weekly weight gain $(\mathrm{kg} / \mathrm{bird})$ & $0.24^{\mathrm{b}}$ & $0.26^{a}$ & 0.007 & 0.028 & 0.24 & 0.25 & 0.007 & 0.094 \\
\hline Daily water intake (I/bird) & 0.22 & 0.21 & 0.032 & 0.868 & 0.21 & 0.22 & 0.032 & 0.737 \\
\hline Weekly feed intake (kg/bird) & 0.76 & 0.74 & 0.033 & 0.709 & 0.74 & 0.76 & 0.033 & 0.604 \\
\hline Feed conversion ratio & 3.32 & 2.94 & 0.184 & 0.162 & 3.17 & 3.09 & 0.184 & 0.750 \\
\hline \multirow[t]{3}{*}{ Survival (\%) } & 95.0 & 93.9 & 2.05 & 0.697 & 95.4 & 93.5 & 2.05 & 0.521 \\
\hline & \multicolumn{8}{|c|}{ water temperature $\mathrm{x}$ vitamin $\mathrm{C}$} \\
\hline & & Drd-C & Ord $+C$ & Cold-C & & $d+C$ & \pm SEM & $\mathrm{p}$ \\
\hline Initial liveweight @ 4 weeks of age $(\mathrm{kg})$ & & 0.50 & 0.51 & 0.50 & 0. & & 0.003 & 0.849 \\
\hline Final liveweight @ 8 weeks of age $(\mathrm{kg})$ & & 1.44 & 1.46 & 1.47 & 1. & & 0.034 & 0.335 \\
\hline Total weight gain $(\mathrm{kg})$ & & 0.93 & 0.95 & 0.97 & 1. & & 0.035 & 0.346 \\
\hline Weekly weight gain $(\mathrm{kg} / \mathrm{bird})$ & & 0.23 & 0.24 & 0.24 & 0. & & 0.009 & 0.213 \\
\hline Daily water intake (I/bird) & & 0.21 & 0.23 & 0.20 & 0. & & 0.045 & 0.989 \\
\hline Weekly feed intake (kg/bird) & & 0.73 & 0.79 & 0.75 & 0. & & 0.046 & 0.366 \\
\hline Feed conversion ratio & & 3.22 & 3.41 & 3.12 & 2. & & 0.261 & 0.301 \\
\hline Survival (\%) & & 96.8 & 93.2 & 94.0 & 93 & & 2.90 & 0.572 \\
\hline
\end{tabular}

${ }^{a b}$ Means in the same row with different superscripts differ significantly $(p<0.05)$.

ORD-C $=$ ordinary water $(25-300 C)$ without vitamin $C$ supplementation; ORD $+C=$ ordinary water (25$300 \mathrm{C}$ ) with vitamin C supplementation (0.5 g/litre water); COLD-C $=$ cold water (5-100C) without vitamin C supplementation; $C O L D+C=$ cold water $(5-100 C)$ without vitamin $C$ supplementation ( $0.5 \mathrm{~g} /$ litre water).

slaughter weight, dressed weight and relative weights of breast meat, liver, spleen, gizzard, drumstick, thigh and heart. The results show that broilers offered cold water had bigger spleen $(\mathrm{p}<0.05)$ and smaller wing $(\mathrm{p}<0.05)$ than birds on water at ambient temperature respectively.

Addition of vitamin $\mathrm{C}$ to drinking water of broiler chickens had no ( $p>0.05$ ) effect on slaughter weight, dressed weight and relative weights of liver, spleen, gizzard, drumstick, thigh, heart and wing. However, breast meat yield differs significantly $(p<0.05)$ between birds that received 0 and
$500 \mathrm{mg}$ vitamin C per litre water. Addition of $500 \mathrm{mg}$ vitamin C per litre drinking water increased the size of breast meat in broiler chickens.

\section{DISCUSSION}

Birds that were offered cold water gained more weight and had higher final weight than birds offered water at ambient temperature. Howlider and Rose (1987) and May et al. (2000) reported that growth rate is reduced in broiler birds when environmental temperature rises because energy 
obtained from the small feed consumed is expended in panting. The result is that heatstressed birds had lower final body weight. One of physiological response to heat stress is the release of corticosterone from the adrenals of chickens. Information concerning the effects of corticosteroids similar to those produced under stress has shown that corticosteroids in poultry can cause decreased body weight gains (Gross and Siegel, 1981). With cold water, the effects of heat stress are ameliorated and so the birds were able to gain more weight. Broilers birds had been reported to have faster growth rate when given cold water under heat stress conditions (Harris et al., 1975). In another experiment however, Okelo et al. (2003) reported that cold water had no effect on liveweight gain in broiler chickens. Lofgreen et al. (1975) reported that British cattle in hot environment consumed more feed and gained more weight when given water cooled to $18.3^{\circ} \mathrm{C}$ compared to $32.2^{\circ} \mathrm{C}$. White Rock broiler however showed no effect of cooled drinking water on liveweight gain (Degen et al., 1992). The present result might be due to reduction in panting rate of birds that received cold water and maintenance of homeostasis in the birds (Abioja, 2010).

Water temperature had no effect on water intake, weekly feed intake and feed conversion ratio. However, previous studies proved that cooled drinking water stimulates water intake (Janssen and Musharaf, 1984; Puma et al., 2001; Butcher and Miles, 2003) in both laying and broiler chickens. Glatz (2001) reported that feed intake of Australian tinted egg laying hens was improved by cold water for the first four weeks of treatment but thereafter, there was a decline in the effectiveness of chilled water to stimulate an increase in feed intake unlike the European brown egg layers which had improved feed

Table IV. Effects of water temperature and vitamin $C$ supplementation on relative weight of body and internal organs (\%) of broiler chickens reared during hot-dry season. (Efecto de la temperatura del agua y la suplementación con vitamina $C$ sobre el peso relativo del cuerpo y órganos internos (\%) de pollos broiler criados durante la estación cálida-seca).

\begin{tabular}{|c|c|c|c|c|c|c|c|c|c|c|c|}
\hline \multirow[b]{2}{*}{ *Parameter } & \multirow{2}{*}{$\begin{array}{c}\text { water } \\
\text { Ord }\end{array}$} & \multicolumn{2}{|c|}{ temperature } & \multicolumn{3}{|c|}{ vitamin C } & \multicolumn{5}{|c|}{ water temperature $\mathrm{x}$ vitamin $\mathrm{C}$} \\
\hline & & Cold & \pm SEM & $-C$ & $+C$ & \pm SEM & Ord-C & Ord $+C$ & Cold-C & Cold $+C$ & \pm SEM \\
\hline Live-weight (g) & 1442 & 1398 & 19.2 & 1423 & 1417 & 19.2 & 1450 & 1433 & 1397 & 1400 & 27.2 \\
\hline Slaughter weight & 96.9 & 95.4 & 1.31 & 95.2 & 97.0 & 1.31 & 96.1 & 97.6 & 94.3 & 96.4 & 1.86 \\
\hline Dressed weight & 89.3 & 88.9 & 1.31 & 88.9 & 89.3 & 1.31 & 88.7 & 90.0 & 89.0 & 88.6 & 1.85 \\
\hline Breast meat & 17.8 & 17.6 & 0.46 & $16.9^{\mathrm{b}}$ & $18.5^{\mathrm{a}}$ & 0.46 & 17.0 & 18.5 & 16.9 & 18.4 & 0.66 \\
\hline Liver & 2.9 & 3.0 & 0.17 & 2.9 & 3.0 & 0.17 & 2.9 & 2.9 & 3.0 & 3.1 & 0.24 \\
\hline Spleen & $0.12^{\mathrm{b}}$ & $0.17^{\mathrm{a}}$ & 0.013 & 0.14 & 0.14 & 0.013 & 0.13 & 0.10 & 0.15 & 0.18 & 0.019 \\
\hline Neck & 3.4 & 3.2 & 0.16 & 3.2 & 3.4 & 0.16 & 3.3 & 3.5 & 3.2 & 3.3 & 0.23 \\
\hline Head & 2.7 & 2.6 & 0.05 & 2.6 & 2.6 & 0.05 & 2.7 & 2.7 & 2.5 & 2.6 & 0.07 \\
\hline Leg & 5.1 & 4.5 & 0.22 & 4.8 & 4.8 & 0.22 & 5.0 & 5.2 & 4.6 & 4.4 & 0.31 \\
\hline Gizzard & 2.7 & 2.8 & 0.20 & 2.8 & 2.7 & 0.20 & 2.7 & 2.8 & 3.0 & 2.6 & 0.28 \\
\hline Drumstick & 10.3 & 9.8 & 0.45 & 10.2 & 9.9 & 0.45 & 10.7 & 9.9 & 9.8 & 9.8 & 0.63 \\
\hline Thigh & 10.4 & 10.1 & 0.38 & 10.2 & 10.4 & 0.38 & 10.8 & 10.1 & 9.6 & 10.6 & 0.53 \\
\hline Heart & 0.51 & 0.53 & 0.028 & 0.53 & 0.50 & 0.028 & 0.53 & 0.48 & 0.53 & 0.52 & 0.040 \\
\hline Wing & $8.1^{a}$ & $7.0^{\mathrm{b}}$ & 0.31 & 7.7 & 7.4 & 0.31 & 8.0 & 8.3 & 7.5 & 6.6 & 0.43 \\
\hline Back & 15.4 & 15.0 & 0.46 & 15.1 & 15.3 & 0.46 & 15.3 & 15.5 & 15.0 & 15.1 & 0.65 \\
\hline
\end{tabular}

*Percentage of live-weight; a,b Means with different superscripts in the same row differ significantly $(p<0.05)$. 
intake throughout the 12 weeks experimental period. But Okelo et al. (2003) had earlier stated that cooled water did not affect feed/ gain ratio in broiler chickens.

Addition of vitamin $\mathrm{C}$ had no effect on weekly weight, total weight gain, final liveweight and water intake in this study. This is in contrast to the reports of Gross (1988) and Mbajiorgu et al. (2007) that addition of ascorbic acid to feed of poultry increased weight gain. Sobayo (2005) also reported that feeding growing pullets with $300 \mathrm{~g}$ vitamin $\mathrm{C} / \mathrm{kg}$ feed during dry season resulted in better weight gain. Overall feed conversion ratio was not affected by vitamin C in broilers' drinking water.

Neither water temperature nor addition of vitamin $C$ had effect on survival of broiler chickens during hot-dry season. The reason for this could not be ascertained because percentage survival was similar for all groups in all other weeks of experiment. The present finding of non-significant effect of water temperature on survival of broiler is contrary to previous reports that chickens offered cold drinking water had better survival rate of (Fox, 1951; Miller and Sunde, 1975; Janssen and Musharaf, 1984; Butcher and Miles, 2003). However, it corroborates the findings in an experiment with Cobb $\mathrm{x}$ Cobb broilers offered water in the range $10.0^{\circ} \mathrm{C}$ to $43.3^{\circ} \mathrm{C}$ by Beker and Teeter (1994). There was no difference in survivability, not even when supplemented with $0.5 \% \mathrm{KCl}$. Okelo et al. (2003) also reported no difference in cumulative mortality of broilers given drinking water of different temperatures. Mortality was only lowered when the chilled water was carbonated. However, it must be borne in mind that breed, stress pattern and bird acclimatization strongly impact on such results. Other researchers adding different substances such as $\mathrm{CO}_{2}, \mathrm{NH}_{4} \mathrm{Cl}, \mathrm{HCl}$, Teeter (1994) had stated that efforts to increase feed consumption of broiler chickens during heat stress have been shown to decrease survival (Teeter, 1994). In this study, the chickens were not forced-fed and had simi- lar weekly feed intake (table IV). This may explain the similarity in survivability of the broilers.

Of the parts of the body and organs observed, spleen and wing were affected by water temperature. Cold water increased relative weights of spleen and lowered the wing compared with the birds offered water at ambient temperature. Information concerning the effects of corticosteroids similar to those produced under stress has shown that corticosteroids in poultry can cause atrophy of the spleen (Gross and Siegel, 1981; Rosales 1994). Spleen is an organ that creates lymphocytes for the destruction and recycling of old red-blood cells. This enabled birds offered cold water to cope with heat stress. Reduced wing will also help in heat dissipation through ventilation of the under skin. Cahaner (2008) had reported benefits of reduced feathering in heat dissipation in broilers. Reducing wings may also help in combating effects of heat stress in broiler chickens. Vitamin C addition to drinking water of broiler chickens increased relative weight of breast meat. This in agreement with the report of Mbajiorgu et al. (2007) that increasing ascorbic acid supplementation increased dressing percentage and breast meat yield at 42 days old Ross 308 broilers. Hot conditions negatively affect yield and quality of broiler breast meat (Leenstra and Cahaner, 1992; Sandercock et al., 2001). This finding shows that with addition of vitamin $\mathrm{C}$ to drinking water of broilers, this effect of heat stress could be ameliorated.

\section{CONCLUSION}

Cold water increased weekly and total weight gain, final liveweight and relative weight of spleen but reduced the weight of wings of broiler chickens compared with birds that received water at ambient temperature during hot-dry season. Addition of vitamin $\mathrm{C}$ to drinking water of broilers had no effect on growth rate but increased breast meat yield in broilers. 


\section{ABIOJA, OSINOWO, SMITH, ERUVBETINE AND ABIONA}

\section{REFERENCES}

Abioja, M.O. 2005. Physiological and haematological responses of West African Dwarf and Red Sokoto goats to water restriction in the humid tropical condition of South-western Nigeria. M. Agric. Dissertation. Department of Animal Breeding and Genetics. University of Agriculture. Abeokuta. Ogun. Nigeria. 78 pp.

Abioja, M.O. 2010. Temperature-humidity effects on egg fertility and evaluation of vitamin $\mathrm{C}$ and cold water on broiler growth in hot season. PhD Thesis. Department of Animal Physiology. University of Agriculture. Abeokuta. Nigeria. $165 \mathrm{pp}$.

Abioja, M.O., Osinowo, O.A., Adebambo, O.A., Bello, N.J. and Abiona, J.A. 2010. Water restriction in goats during hot-dry season in the humid tropics: feed intake and weight gain. Arch. Zootec., 59: 195-203.

Abu-Dieyeh, Z.H.M. 2006. Effect of chronic heat stress and long-term feed restriction on broiler performance. Int. J. Poult. Sci., 5: 185-190.

Beker, A. and Teeter, R.G. 1994. Drinking water temperature and potassium chloride supplementation effects on broiler body temperature and performance during heat stress. J. Appl. Poult. Res. 3: 87-92.

Brake, J.T. 1987. Stress and modern poultry management: animal production highlights. $F$. Hoffman-La Roche \& Co. Ltd. Basle. Switzerland.

Butcher, G.D. and Miles, R. 2003. Heat stress management in broilers. IFAS Extension. University of Florida. USA VM65: 1-3.

Cahaner, A. 2008. Breeding broilers for hot conditions. Nig. Poult. Sci. J., 5: 156-163.

Degen, A.A., Kam, M. and Rosenstrauch, A. 1992. Effect of restricted cooled drinking water on the performance of broiler breeder hens in a hot, dry climate. Brit. Poult. Sci., 33: 917-924.

Fox, T.L. 1951. Studies on heat tolerance in the domestic fowl. Poult. Sci., 30: 477-483.

Genç, L. 2005. Sensible and latent heat productions from broilers in laboratory conditions. Turkey $\mathrm{J}$. Vet. Anim. Sci., 29: 635-643.

Glatz, P.C. 2001. Effect of cool drinking water on production and shell quality of laying hens in summer. Anim. Sci., 14: 850-854.

Google Earth. 2006. http://www.google.earth (01/ 28/10).
Gross, W. B. 1988. Effect of ascorbic acid on the mortality of Leghorn-type chickens due to overheating. Avian Dis., 32: 561-562.

Gross, W.B. and Siegel, P.B. 1981. Long-term exposure of chickens to three levels of social stress. Avians, 25: 312-325.

Hai, L., Rong, D. and Zhang, Z.Y. 2000. The effect of thermal environment on the digestion of broilers. J. Anim. Physiol. Anim. Nutr., 83: 5764.

Harris, G.C., Nelson, G.S., Seay, R.L. and Dodgen, W.H. 1975. Effects of drinking water temperature on broiler performance. Poult. Sci., 54: 775779.

Howlider, M.A.R. and Rose, S.P. 1987. Temperature and the growth of broilers. World's Poult. Sci. J., 43: 228-237.

Janssen, W.M.M.A. and Musharaf, N.A. 1984. Effects of water temperature and feed density on the performance of laying hens kept under thermal stress. Proc. International Poultry Conference. Frankfurt. Germany. pp. 1-12.

Leenstra, F. and Cahaner, A. 1992. Effects of low, normal and high temperatures on slaughter yield of broilers from lines selected for high weight gain, favourable feed conversion and high and low fat content. Poult. Sci., 71: 1994-2006.

Lofgreen, G.P., Given, R.L., Morrison, S.R. and Bond, T.E. 1975. Effect of drinking water temperature on beef cattle performance. J. Anim. Sci., 40: 223-229.

Mahmoud, K.Z., Edens, F.W., Eisen, E.J. and Havenstein, G.B. 2004. Ascorbic acid decreases heat shock protein 70 and plasma corticosterone response in broilers (Gallus gallus domesticus) subjected to cyclic heat stress. Comp. Biochem. Physiol. B, 137: 35-42.

May, J.D., Lott, B.D. and Simmons, J.D. 2000. The effect of air velocity on broiler performance and feed and water consumption. Poult. Sci., 79: 1396-1400.

Mbajiorgu, C.A., Ng'ambi, J.W. and Norris, D. 2007. Effect of time of initiation of feeding after hatching and influence of dietary ascorbic acid supplementation on productivity, mortality and carcass characteristics of Ross 308 broiler chickens in South-Africa. Int. J. Poult. Sci., 6: 583-591. 


\section{EVALUATION OF COLD WATER AND VITAMIN C ON BROILER GROWTH}

Miller, P.C. and Sunde, M.L. 1975. The effect of precise constant and cyclic environments on shell quality and other lay performance factors with leghorn pullets. Poult. Sci. 54: 36-46.

Okelo, P.O., Carr, L.E., Harrison, P.C., Douglass, L.W., Byrd, V.E., Wabeck, C.W., Schreuders, P.D., Wheaton, F.W. and Zimmermann, N.G. 2003. Trans. ASAE, 46: 453-460.

Oskan, S., Akbas, Y., Altan, O., Ayhan, V. and Ozkan, K. 2003. The effect of short-term fasting on performance of traits and rectal temperature of broilers during the summer season. Brit. Poult. Sci., 44: 88-95.

Palmer, C. 2000. Humidity formulas. Today's Information Network, USA. www.humidity.com (12/05/03).

Pardue, S.L. and Thaxton, J.P. 1986. Ascorbic acid in poultry: a review. World's Poult. Sci. J., 42: 107-123.

Pardue, S.L., Thaxton, J.P. and Brake, J. 1985. Role of ascorbic acid in chicks exposed to high environmental temperature. J. Appl. Physiol., 58: 1511-1516.

Puma, M.C., Xin, R.S., Gates, R.S. and Ahn, D.U. 2001. Effects of drinking water temperature on laying hens subjected to warm cyclic environmental conditions. In: Stowell, R. R., Bucklin, R. and Bottcher, R. W. (Eds.). Livestock environment. Proc. $6^{\text {th }}$ Int. Symp. May 21-23. Louisville. Kentucky. pp. 235-243.

Rosales, A.G. 1994. Managing heat stress in broiler breeders: a review. J. Appl. Poult. Res.,
3: $199-207$.

Sahin, K. 2003. Effects of chromium and ascorbic acid supplementation on growth, carcass traits, serum metabolites and antioxidant status of broiler chickens reared at a high ambient temperature $\left(32^{\circ} \mathrm{C}\right)$. Nutr. Res., 23: 225-238.

Sandercock, D.A., Hunter, R.R., Nute, G.R. and Mitchell, M.A. 2001. Acute heat stress induced alterations in blood acid base status and skeletal muscle membrane in broiler chickens at two ages: implication for meat quality. Poult. Sci., 80: 418-425.

Sobayo, R.A. 2005. Effect of ascorbic acid supplementation on the performance and haematological profile of pullets and layers. PhD thesis. Department of Animal Nutrition. University of Agriculture. Abeokuta. Nigeria. 214 pp.

SYSTAT 1992. Systat analytical computer package (version 5.0). Systat Inc. USA.

Teeter, R. G. 1994. Optimizing production of heat stressed broilers. Poult. Dig., 5: 10-16.

Temim, S., Chagneau, A.M., Guillaumin, S., Michael, J., Peresson, R. and Tesseraud, S. 2000. Does excess dietary protein improve growth performance and carcass characteristics in heatexposed chickens? Poult. Sci., 79: 312-317.

Wilson, W.O. and Edwards, W.H. 1952. Response of hen's thermal stress to hydration and chilled drinking water. Amer. J. Physiol., 169: 102-107.

Yahav, S. 2000. Domestic fowl: strategies to confront environmental conditions. Av. Poult. Biol. Rev., 11: 81-95. 